\title{
Efektivitas pengolahan limbah cair industri penyamakan kulit Sukaregang Garut dengan adsorben karbon aktif dan ijuk
}

\author{
R. Fachria ${ }^{1 *}$, H. Ramdan², I. N. P. Aryantha ${ }^{3}$ \\ ${ }^{1}$ Jurusan Biomanajemen, Institut Teknologi Bandung, Bandung, Indonesia \\ ${ }^{2}$ Kelompok Keahlian Manajemen Sumberdaya Hayati, Institut Teknologi Bandung, Bandung, Indonesia \\ ${ }^{3}$ Kelompok Keahlian Bioteknologi Mikroba, Institut Teknologi Bandung, Bandung, Indonesia
}

\begin{abstract}
Abstrak.
Penyamakan kulit termasuk dalam industri andalan Indonesia. Salah satu wilayah yang menghasilkan bahan kulit berkualitas adalah Sukaregang, Garut. Industri ini memiliki dampak positif dan negatif. Limbah cair dari penyamakan kulit mencemari lingkungan dan menurunkan kualitas kesehatan masyarakat. Oleh karena itu, pengusaha harus memiliki teknologi pengolahan mandiri. Salah satu metode pengolahan yang dapat diterapkan adalah metode adsorpsi. Tujuan dari penelitian ini adalah mengukur efektivitas pengolahan limbah cair penyamakan kulit dengan metode adsorpsi. Penelitian dilakukan dalam dua tahap, yaitu penelitian pendahuluan untuk menentukan adsorben dan penelitian lanjutan untuk mengukur efektivitas pengolahan. Lokasi penelitian adalah pabrik Kamila Leather di Sukaregang Garut. Penilaian berdasarkan parameter baku mutu dalam PerMenLH Nomor 5 Tahun 2014 tentang Baku Mutu Air Limbah. Hasilnya, melalui metode adsorpsi dengan adsorben arang aktif dan ijuk dapat menurunkan 72,13\% TSS, 76,58\% BOD dan $76,49 \%$ COD.
\end{abstract}

Kata kunci: penyamakan, limbah cair, adsorpsi, arang aktif, ijuk

\begin{abstract}
.
Tannery is one of main field in Indonesian industry. One area that produces quality leather is Sukaregang, Garut. This industry has positive and negative impacts. Wastewater from tannery pollutes the environment and decreases the quality of public health. Therefore, entrepreneurs must have independent processing technology. One of the processing methods that can be applied is the adsorption method. The purpose of this study is to measure the effectiveness of tannery wastewater treatment by adsorption methods. The study was conducted in two stages, namely preliminary research to determine adsorbents and further research to measure the effectiveness of processing. The research location is the Kamila Leather factory in Sukaregang Garut. The assessment is based on the quality standard parameters in Minister of Environment Regulation Number 5 Years 2014 on Wastewater Quality Standards. The result, through the adsorption method with activated carbon adsorbent and palm fiber, can reduce $72.13 \%$ TSS, $76.58 \%$ BOD and $76.49 \%$ COD.
\end{abstract}

Keywords: tannery, wastewater, adsorption, activated carbon, palm fiber

\section{PENDAHULUAN}

Kerajinan kulit termasuk dalam industri andalan di Rencana Induk Pembangunan Nasional (RIPIN) 2015-2035. Nilai ekspor dari industri kulit Indonesia mencapai 330.700.000 USD pada bulan Juni 2018 (Kemenperin 2018). Indonesia memiliki beberapa tempat produksi bahan kulit, salah satu daerah yang terkenal menghasilkan bahan berkualitas adalah Sukaregang, Kabupaten Garut. Kabupaten Garut memiliki 330 pengusaha penyamakan kulit yang tersebar di wilayah seluas 57,750 ha. Adapun total bahan kulit yang dihasilkan wilayah Sukaregang mencapai $10.634 \mathrm{~m}^{2}$, baik yang berasal dari bahan baku kulit domba maupun sapi (DLHKP Kabupaten Garut 2014).

Industri kerajinan kulit ini memiliki dampak positif bagi perekonomian dan dampak negatif bagi lingkungan. Sebesar 99\% pengusaha tidak memiliki

\footnotetext{
${ }^{*}$ Korespondensi Penulis

Email : rizqy.fachria@gmail.com
} 
teknologi pengolahan limbah industri baik limbah cair, padat maupun gas. DLHKP Kabupaten Garut (2014) melaporkan bahwa kegiatan penyamakan kulit di Sukaregang menghasilkan air limbah sebanyak 90.000 liter/bulan yang dibuang langsung ke badan sungai. Akibatnya, lahan pertanian yang tercemar mengalami penurunan produksi, usaha budidaya perikanan mati, serta kualitas hidup masyarakat yang tinggal di sekitar aliran sungai menjadi menurun. Pemerintah telah berupaya mengatasi dampak-dampak negatif yang ditimbulkan dengan pembuatan tiga unit Instalasi Pengelolaan Air Limbah (IPAL) yang berkapasitas $600 \mathrm{~m}^{3} /$ hari. Sayangnya, ketiga IPAL ini tidak dapat dioperasikan karena kondisinya yang rusak berat akibat ketiadaan biaya operasional dan unit pengelola yang kompeten.

Para pelaku usaha diwajibkan untuk memiliki pengolahan limbah mandiri. Namun, status para penyamak kulit di Garut masih termasuk dalam golongan usaha mikro kecil dan menengah. Oleh karena itu, teknologi yang ditawarkan harus dapat terjangkau oleh para pelaku usaha. Beberapa hasil penelitian terkait yang telah dilakukan menginformasikan pengolahan limbah kulit dapat dilakukan dengan pemanfaatan karbon aktif sebagai penjerap limbah (Tatra 2014), prototipe IPAL dengan sistem daur ulang (El-Hadi dan Nasution 2012), pengolahan dengan metode elektrokoagulasi (Ringo et al. 2013), aplikasi pemulihan kromium (Dzikron 2014), uji toksisitas air limbah (Priyanto 2006), agen fitoremediasi (Putri et al. 2014), proses presipitasi dan adsorpsi dalam pengolahan limbah (Wardhani et al. 2011) dan teknologi M-Bio untuk pengolahan limbah padat (Priyadi et al. 2014).

Hampir seluruh hasil penelitian tersebut dilakukan hanya pada skala laboratorium, belum ada penelitian yang dilakukan dalam skala lanjut (pilot) maupun industri. Metode pengolahan yang mungkin dapat diterapkan oleh pengusaha penyamak kulit adalah metode adsorpsi. Metode ini tidak membutuhkan biaya yang besar dan proses pengolahan yang mudah. Adsorpsi adalah kejadian menempelnya suatu zat (adsorbat) pada permukaan zat lain (adsorben) karena adanya gaya tarik dari permukaan zat. Adsorpsi dapat terjadi karena adanya gaya tarik Van der Waals (adsorpsi fisik atau fisisorpsi) atau dapat bersifat kimia (kemisorpsi) (Dabrowski 2001). Tujuan dari penelitian ini adalah melihat efektivitas pengurangan parameter pencemar dari limbah cair penyamakan kulit dengan metode adsorpsi.

\section{METODOLOGI}

\subsection{Lokasi kajian dan waktu penelitian}

Penelitian dilakukan dalam dua tahapan, yakni pengujian pendahuluan dan pengujian lanjut. Pengujian pendahuluan dilakukan di Laboratorium Mikologi Gedung Pusat Antar Universitas (PAU) Institut Teknologi Bandung (ITB). Pabrik 
Kamila Leather menjadi lokasi pengambilan sampel air limbah dan uji coba sistem pengolahan limbah cair. Sampel limbah sebelum pengolahan dan setelah pengolahan dianalisis di Laboratorium Sucofindo. Penelitian dimulai sejak bulan Juni 2018 hingga April 2019.

\subsection{Prosedur analisis data}

\subsubsection{Karakterisasi limbah penyamakan kulit dari pabrik}

Pengambilan sampel limbah cair dilakukan dengan cara gabungan tempat (integrated sample) yakni sampel gabungan diambil dari beberapa tempat secara terpisah dengan volume yang sama (Effendi 2003). Sampel air limbah ini dibawa ke Laboratorium Sucofindo untuk dianalisis.

\subsubsection{Uji pendahuluan sistem pengolahan limbah dengan metode adsorpsi skala lab}

Uji pendahuluan dilakukan untuk menguji beberapa jenis bahan penjerap yang dapat digunakan dalam pengolahan limbah secara adsorpsi. Bahan yang akan berpotensi untuk digunakan adalah arang, arang aktif, serabut kelapa, ijuk dan campuran dari semua bahan. Sebanyak 25 gram dari tiap bahan penjerap dimasukkan ke dalam botol Erlenmeyer plastik. Kemudian ditambahkan kalium dikromat $\mathrm{K}_{2} \mathrm{Cr}_{2} \mathrm{O}_{7}$ (larutan kromium buatan) konsentrasi 100 ppm sebanyak 100 $\mathrm{ml}$. Botol Erlenmeyer yang telah diisi bahan penjerap dan larutan kromium buatan diinkubasi 21 jam. Botol diaduk dengan kecepatan 40 per menit. Parameter yang diukur adalah nilai $\mathrm{pH}$ dan konsentrasi kromium setelah masa inkubasi. Nilai $\mathrm{pH}$ diukur dengan $\mathrm{pH}$ meter, sedangkan jumlah kromium diukur melalui pengujian di Laboratorium Hidrometalurgi ITB.

\subsubsection{Uji lanjut sistem pengolahan limbah metode adsorpsi skala pilot}

Uji pendahuluan sebelumnya menunjukkan bahwa ijuk dan arang aktif dapat menurunkan kromium serta meningkatkan pH. Pada uji lanjut dilakukan dengan sistem kolom sirkulasi tertutup (Gambar 1). Kolom yang digunakan sebanyak 4 buah yang diisi dengan ijuk, karbon aktif, ijuk dan karbon aktif. Sebanyak $12 \mathrm{~kg}$ karbon aktif dimasukkan ke dalam kolom hingga mencapai tinggi 38,5 cm dari dasar kolom. Ijuk yang dimasukkan ke kolom memiliki tinggi $46,5 \mathrm{~cm}$ dari dasar kolom. Sebanyak 81 liter limbah campuran dari proses pencelupan, penyamakan dan dari bak pengendapan diolah dengan mengalirkannya ke tabung-tabung sistem. Pada uji ini diamati perubahan $\mathrm{pH}$, warna dan bau dari limbah hasil pengolahan. Limbah yang diolah merupakan limbah campuran yang berasal dari bak pengapuran, molen penyamakan dan molen pewarnaan. Ketiga limbah dicampur dengan volume yang sama. Limbah tersebut dialirkan ke dalam kolom tabung berisi bahan penjerap selama 48 jam.

Selama proses adsorpsi, dilakukan pengamatan dengan mengukur perubahan $\mathrm{pH}$ tiap jamnya selama 24 jam. Setelah 48 jam, limbah yang telah 
diolah diuji di Laboratorium Sucofindo. Parameter yang diuji adalah nilai $\mathrm{pH}$, total suspended solid (TSS), BOD 5 , COD, fenol, total kromium, total amonium, sulfida, minyak dan lemak. Parameter tersebut mengacu pada PerMenLH Nomor 5 Tahun 2014 tentang Baku Mutu Air Limbah dari pabrik penyamakan kulit.

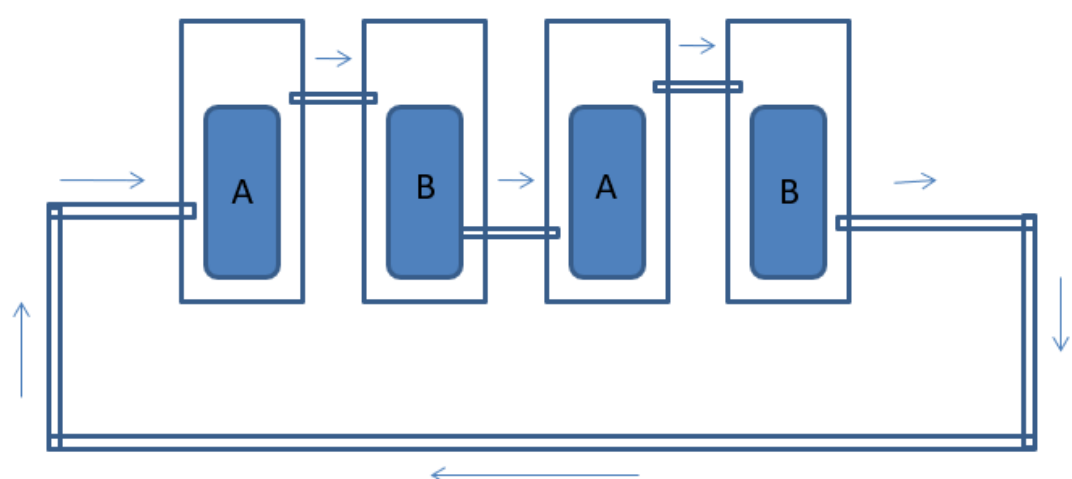

Gambar 1. Diagram proses prototipe pada pengujian lanjut ( $A=$ arang aktif; $B=i j u k)$.

\section{HASIL DAN PEMBAHASAN}

\subsection{Karakteristik limbah penyamakan kulit}

Sebelum merancang sistem pengolahan limbah, karakteristik limbah dari penyamakan kulit pabrik harus diketahui. Limbah penyamakan yang dianalisis berasal dari proses pengapuran $(\mathrm{pH} 9,58)$, proses penyamakan $(\mathrm{pH} 2,48)$ dan proses pewarnaan (pH 11,08). Kemudian, semua sumber air limbah dicampur dengan volume yang sama. Nilai $\mathrm{pH}$ dari limbah campuran tiap proses ini adalah 3,6. Limbah campuran berwarna hijau kebiruan, memiliki padatan terlarut berwarna putih dan bau busuk yang pekat. Warna biru berasal dari kromium dan pewarna kulit. Bau busuk yang pekat tersebut diduga berasal dari proses pengapuran yang menggunakan sulfur. Selanjutnya, limbah tersebut diuji karakteristiknya berdasarkan PerMenLH Nomor 5 Tahun 2014 (Tabel 1).

Tabel 1. Karakteristik limbah berdasarkan parameter baku mutu air limbah penyamakan kulit.

\begin{tabular}{lccc}
\hline Parameter & Satuan & $\begin{array}{c}\text { Konsentrasi limbah } \\
\text { (sebelum pengolahan) }\end{array}$ & Baku mutu \\
\hline pH lapangan & - & $3,6^{*}$ & $6,0-9,0$ \\
Total Suspended Solid (TSS) & $\mathrm{mg} / \mathrm{l}$ & $409^{*}$ & 60 \\
$\mathrm{BOD}_{5} 20^{\circ} \mathrm{C}$ & $\mathrm{mg} / \mathrm{l}$ & $301^{*}$ & 50 \\
$\mathrm{COD}$ dari $\mathrm{K}_{2} \mathrm{Cr}_{2} \mathrm{O}_{7}$ & $\mathrm{mg} / \mathrm{l}$ & $1004^{*}$ & 110 \\
Fenol & $\mathrm{mg} / \mathrm{l}$ & 0,10 & 0,50 \\
Total Kromium & $\mathrm{mg} / \mathrm{l}$ & $<0,08$ & 0,60 \\
Total Amonium $\left(\mathrm{NH}_{3}-\mathrm{N}\right)$ & $\mathrm{mg} / \mathrm{l}$ & 0,26 & 0,5 \\
Sulfida & $\mathrm{mg} / \mathrm{l}$ & $<0,01$ & 0,8 \\
Minyak dan Lemak & $\mathrm{mg} / \mathrm{l}$ & $<2$ & 5 \\
\hline
\end{tabular}

Keterangan: *melebihi baku mutu 
Berdasaran karakteristik tersebut, diketahui bahwa parameter yang melebihi baku mutu adalah nilai $\mathrm{pH}(3,6)$, total padatan tersuspensi atau TSS (409 mg/l), BOD 5 (301 mg/l) dan COD (1,004 mg/l). Nilai TSS, BOD dan COD yang tinggi menunjukkan konsentrasi zat organik yang tinggi. Terlebih pada parameter COD yang nilainya tiga kali lipat dari nilai BOD. Hal ini menunjukkan kandungan organik pada penyamakan kulit sulit diuraikan organisme (Weiner and Matthews 2003). Faktor penyebabnya adalah tingginya konsentrasi senyawa toksik yang digunakan dalam proses produksi. Toksisitas dari tiap proses produksi berbeda nilainya. Proses pengapuran menghasilkan limbah dengan toksisitas 76\%, sedangkan penyamakan memiliki toksisitas $24 \%$. Penyumbang BOD dan COD terbanyak berasal dari proses pengapuran dengan nilai masing-masing $70 \%$ dan $55 \%$.

Tiap pabrik akan menghasilkan nilai yang berbeda bergantung dari kapasitas produksi, jenis senyawa kimia yang digunakan, serta proses yang berlangsung. Misalnya pada penelitian Wardhani et al. (2011) melaporkan parameter yang melebihi baku mutu adalah TSS $(6.528,00 \mathrm{mg} / \mathrm{l}), \mathrm{BOD}_{5}(475,00$ $\mathrm{mg} / \mathrm{l}), \operatorname{COD}(811,19 \mathrm{mg} / \mathrm{l})$ dan total kromium $(86,08 \mathrm{mg} / \mathrm{l})$. Contoh lainnya adalah penelitian Tatra (2014), limbah dari pabrik penyamakan kulit yang diteliti memiliki nilai krom total sebesar 4.371,21 mg/l, nilai BOD sebesar $1.216,10 \mathrm{mg} / \mathrm{l}$, nilai COD sebesar 17.753,33 mg/l dan nilai $\mathrm{pH}$ sebesar 2,68.

Kedua penelitian sebelumnya, memiliki nilai krom total yang melebihi baku mutu. Namun, pada penelitian ini nilai krom total masih jauh dibawah ambang batas baku mutu. Hasil ini diperkuat dengan penelitian Ningrum (2010), logam kromium tidak terdeteksi pada air di hulu maupun di hilir sungai. Namun, logam kromium ditemukan pada lumpur endapan Sungai Ciwalen dan Sungai Cigulampeng. Konsentrasi kromium meningkat pada daerah hilir sungai.

\subsection{Uji metode adsorpsi}

Metode yang diuji pada penelitian ini adalah metode adsorpsi fisik dan sedimentasi. Teknologi adsorpsi telah digunakan sejak abad ke-18. Karbon digunakan sebagai bahan penjerap yang umum digunakan untuk adsorpsi gas, zat cair, zat pewarna dan abu dalam air. Teknologi ini memiliki prinsip yang sederhana dan biaya murah, sehingga sering digunakan untuk pengolahan air. Adsorpsi terjadi melalui tiga tahapan yaitu perpindahan molekul adsorbat mendekati lapisan permukaan adsorben, difusi adsorbat melalui lapisan film permukaan dan penempelan adsorbat pada permukaan adsorben (Wardhani et al. 2011). Adsorpsi akan terjadi jika gaya tarik yang menarik antara zat terlarut dan adsorben lebih besar dari energi kohesif zat itu sendiri. Deskripsi kualitatif dari interaksi adsorbat dan adsorben melalui isoterm adsorpsi dapat digunakan dalam optimasi penggunaan (Itodo et al. 2018). 
Pengujian metode adsorpsi pada penelitian ini menggunakan bahan adsorben yang mengacu pada Khan et al. (2001) dan Gupta and Suhas (2009). Beberapa adsorben yang memiliki daya adsorpsi baik, murah dan mudah ditemukan antara lain arang aktif, arang biasa, serabut kelapa dan ijuk. Keempat bahan tersebut diuji daya serap dan pengaruhnya terhadap nilai $\mathrm{pH}$ dalam skala laboratorium dengan sistem batch selama 21 jam. Erlenmeyer yang berisi larutan kromium dan bahan adsorben diinkubasi selama 21 jam. Berdasarkan hasil uji, bahan penjerap yang meningkatkan nilai $\mathrm{pH}$ paling besar adalah ijuk, sedangkan bahan yang menurunkan konsentrasi kromium paling tinggi adalah arang aktif (Tabel 2). Selain nilai pH dan kromium, melalui pengamatan langsung dapat dilihat perubahan warna yang signifikan dari larutan. Perubahan warna paling signifikan ditunjukkan oleh larutan dengan adsorben arang aktif (Gambar 2). Sebelum masa inkubasi, larutan berwarna kuning, kemudian berubah menjadi bening setelah masa inkubasi. Hasil ini didukung oleh penelitian Ayub and Khorasgani (2014) dan Itodo et al. (2018) yang melaporkan bahwa karbon aktif dari tempurung kelapa dapat mereduksi konsentrasi kromium. Berdasarkan hasil ini, maka ijuk dan arang aktif digunakan dalam uji pengolahan limbah skala pilot.

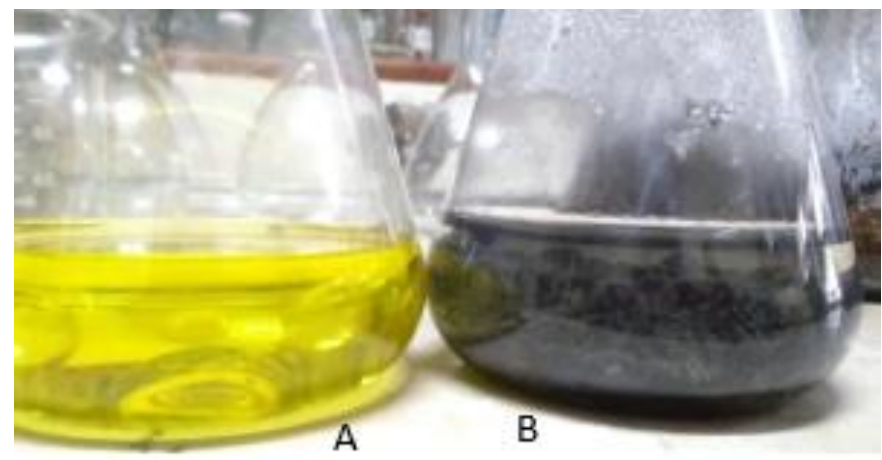

Gambar 2. Perubahan warna sebelum (A) dan sesudah inkubasi (B) dengan adsorben arang aktif.

Tabel 2. Nilai rata-rata kenaikan $\mathrm{pH}$ dan penurunan persen konsentrasi kromium.

\begin{tabular}{clcc}
\hline No & Perlakuan & Rata-rata kenaikan nilai $\mathrm{pH}$ & Rata-rata penurunan kromium (\%) \\
\hline 1 & Arang aktif & 0,07 & 69,05 \\
2 & Arang biasa & 1,24 & 10,80 \\
3 & Serabut kelapa & 1,51 & 41,07 \\
4 & Ijuk & 2,03 & 26,65 \\
5 & Campuran & 1,68 & 52,72 \\
\hline
\end{tabular}

Arang biasa hanya dapat menurunkan konsentrasi kromium sebanyak $10 \%$. Faktor utama penyebabnya adalah ukuran pori arang biasa yang lebih kecil. Arang biasa tidak diberi perlakuan pengasaman seperti arang aktif, 
sehingga ukuran porinya lebih kecil dibandingkan pori arang aktif. Serabut kelapa dapat menurunkan konsentrasi kromium hingga 41\%. Walaupun tidak mencapai 50\%, namun serabut kelapa berpotensi menjadi bahan penjerap karena memiliki gugus karboksil serta lignin yang mengandung asam phenolat yang dapat mengikat logam (Pratama et al. 2016).

Uji pengolahan metode adsorpsi skala pilot dilakukan menggunakan limbah pabrik langsung dari Kamila Leather. Kolom dengan sistem sirkulasi tertutup diisi dengan adsorben hasil uji pendahuluan yaitu ijuk dan arang aktif. Air limbah yang berasal dari proses pengapuran, penyamakan dan pewarnaan dialiri ke dalam kolom tersebut selama 48 jam. Kemudian diamati perubahan $\mathrm{pH}$ di tiap kolom selama 24 jam dengan jeda waktu 1 jam. Setiap 1 jam, sistem menaikkan $\mathrm{pH}$ rata-rata senilai 0,04 . Setelah 18 jam proses pengolahan, $\mathrm{pH}$ naik 1 angka. Selain perubahan $\mathrm{pH}$, warna dan bau dari limbah juga berubah. Warna awal limbah yang semula biru pekat berubah menjadi biru bening dalam waktu 24 jam. Setelah 48 jam, didapat nilai akhir pH dari sistem adsorpsi adalah 5,11. Air limbah hasil pengolahan pada jam ke-24 dan ke-48 dibawa ke laboratorium untuk diuji berdasarkan parameter dalam baku mutu PerMenLH Nomor 5 Tahun 2014 tentang Baku Mutu Air Limbah. Hasil dari pengujian limbah yang telah diolah dengan sistem adsorpsi dapat dilihat pada Tabel 3.

Tabel 3. Hasil pengolahan air limbah dengan metode adsorpsi selama 24 jam dan 48 jam.

\begin{tabular}{lcccc}
\hline Parameter & \multicolumn{3}{c}{ Hasil } & Sebelum \\
\cline { 2 - 4 } & $\begin{array}{c}\text { Pengolahan } \\
(\mathrm{mg} / \mathrm{l})\end{array}$ & $\begin{array}{c}\text { Pengolahan } \\
24 \text { jam } \\
(\mathrm{mg} / \mathrm{l})\end{array}$ & $\begin{array}{c}\text { Pengolahan } \\
48 \text { jam } \\
(\mathrm{mg} / \mathrm{l})\end{array}$ & $\begin{array}{c}\text { Baku mutu } \\
(\mathrm{mg} / \mathrm{l})\end{array}$ \\
\hline $\mathrm{pH}$ & 3,60 & 5,09 & 5,11 & $6,0-9,0$ \\
Total Suspended Solid (TSS) & 409 & 58 & 114 & 60 \\
$\mathrm{BOD} 50^{\circ} \mathrm{C}$ & 301,0 & 95,0 & 70,5 & 50 \\
COD dari $\mathrm{K}_{2} \mathrm{Cr}_{2} \mathrm{O}_{7}$ & 1004 & 318 & 236 & 110 \\
Fenol & 0,100 & 0,030 & $<0,007$ & 0,50 \\
Total Kromium & $<0,08$ & $<0,08$ & $<0,08$ & 0,60 \\
Total Amonium (NH3-N) & 0,26 & 0,24 & 0,40 & 0,5 \\
Sulfida & $<0,01$ & $<0,01$ & $<0,01$ & 0,8 \\
Minyak dan Lemak & $<2$ & $<2$ & $<2$ & 5 \\
\hline
\end{tabular}

Nilai akhir pH sistem $(5,11)$ masih di bawah baku mutu yang ditetapkan yaitu 6,0-9,0. Kombinasi ijuk dan arang aktif ternyata tidak dapat meningkatkan nilai pH hingga mencapai baku mutu. Hasil ini serupa dengan penelitian adsorpsi Tatra (2014) yang menggunakan karbon aktif. Nilai pH dalam penelitiannya hanya berkisar 2,66-2,72. Tatra (2014) menyimpulkan bahwa nilai pH tidak dipengaruhi oleh lama waktu kontak maupun konsentrasi karbon aktif. Faktor penyebab utama dari rendahnya nilai kenaikan $\mathrm{pH}$ adalah terjadi persaingan antara ion $\mathrm{H}^{+}$dengan bahan organik dan kromium yang ada dalam air limbah. 
Daya tarik dari zat organik dan logam lebih besar dari ion $\mathrm{H}^{+}$, sehingga permukaan adsorben lebih banyak menyerap kedua zat tersebut (Tatra 2014).

Parameter yang akan dibahas adalah parameter yang melebihi baku mutu sebelum pengolahan yaitu pH, TSS, BOD dan COD. Konsentrasi TSS sebelum pengolahan mencapai $409 \mathrm{mg} / \mathrm{l}$. Kemudian setelah pengolahan selama 24 jam turun menjadi $58 \mathrm{mg} / \mathrm{l}$. Namun, setelah pengolahan 48 jam nilai TSS meningkat kembali sebesar dua kali lipat menjadi $114 \mathrm{mg} / \mathrm{l}$. Hal ini dapat disebabkan karena ijuk yang berupa serbuk dari kolom ikut terbilas oleh aliran, sehingga meningkatkan nilai TSS pada jam ke 48. Parameter BOD dan COD mengalami penurunan dengan bertambahnya waktu kontak. Setelah 24 jam nilai BOD turun menjadi 95,0 mg/l, kemudian setelah 48 jam terus menurun menjadi 70,5 mg/l. Begitu pula dengan nilai COD yang awalnya sebesar $1.004 \mathrm{mg} / \mathrm{l}$, setelah melalui sistem adsorpsi selama 24 dan 48 jam turun menjadi $318 \mathrm{mg} / \mathrm{l}$ dan $236 \mathrm{mg} / \mathrm{l}$.

Ijuk dan arang aktif memiliki peran dalam menurunkan TSS, BOD dan COD. Pranoto et al. (2018) membuktikan bahwa ijuk dapat menyerap logam berat dari air limbah karena memiliki kandungan selulosa yang tinggi. Karbon aktif juga telah terbukti mampu menurunkan nilai TSS, BOD dan COD. Tatra (2014), Wardhani et al. (2011), Kurniasari et al. (2012), Devi et al. (2012), Ayub dan Khorasgani(2014) dan Itodo et al. (2018) melakukan penelitian mengenai pengolahan air limbah penyamakan kulit menggunakan karbon aktif. Pada penelitian Wardhani et al. (2011), karbon aktif memiliki efisiensi 77\% untuk menurunkan TSS, 94,06\% untuk menurunkan BOD dan 98\% untuk menurunkan COD. Jika dibandingkan dengan penelitian lainnya, sistem kolom dengan ijuk dan karbon aktif selama 48 jam memiliki efektivitas yang lebih rendah yaitu 72,13\% untuk TSS, 76,58\% untuk BOD dan 76,49\% untuk COD. Perbedaan efektivitas disebabkan oleh pebedaan beban pencemaran air limbah yang diolah dalam penelitian. Penurunan nilai TSS, BOD dan COD disebabkan oleh terjadinya proses adsorpsi zat organik. Adsorpsi fisik ini terjadi karena adanya gaya ikatan Van der Waals. Ikatan ini bersifat lemah sehingga memperbesar peluang terjadinya desorpsi yaitu terlepasnya suspensi adsorbat dikarenakan karbon aktif telah mencapai titik jenuh (Kurniasari et al. 2012).

Nilai efektivitas penurunan zat organik dan logam berat dipengaruhi oleh beberapa faktor, yaitu konsentrasi adsorben, waktu kontak, ukuran pori adsorben (Tatra 2014) dan pH (Devi et al. 2012). Semakin tinggi konsentrasi, waktu kontak dan ukuran pori menyebabkan efisiensi penurunanya semakin meningkat. Namun, jika waktu kontak telah mencapai titik jenuh, daya adsorpsi akan berkurang atau bahkan akan melepaskan zat organik. Meena and Rajagopal (2002) menyarankan waktu kontak yang baik untuk penjerapan adalah 48 jam. Waktu ini dapat dipersingkat, jika konsentrasi adsorben ditambah. Pori dari adsorben karbon aktif dapat diperluas dengan pemberian asam kuat. Asam 
memiliki sifat dehidrasi sehingga dapat memperluas ukuran pori permukaan karbon yang akan meningkatkan daya adsopsi (Tatra 2014).

\section{KESIMPULAN DAN SARAN}

Pengolahan limbah cair penyamakan kulit dengan metode adsorpsi selama 48 jam memiliki efektivitas 72,13\% untuk menurunkan TSS, 76,58\% untuk menurunkan BOD dan 76,49\% untuk menurunkan COD. Perusahaan dapat mempertimbangkan untuk menggunakan metode ini dalam pengolahan limbah cair mereka. Penelitian lebih lanjut dalam skala industri diperlukan untuk melihat konsistensi efektivitas metode adsorpsi serta kelayakannya untuk diterapkan.

\section{DAFTAR PUSTAKA}

Ayub S and Khorasgani FC. 2014. Adsorption process for wastewater treatment by using coconut shell. International Journal of Civil, Structural, Environmental and Infrastracture Engineering 4(3):21-34.

Dabrowski A. 2001. Adsorption-from theory to practice. Advances in Colloid and Interface Science 93(1-3):135-224.

Devi BV, Jahagirdar AA and Ahmed MNZ. 2012. Adsorption of chromium on activated carbon prepared from coconut shell. IJERA 2(5):364-70.

[DLHKP] Dinas Lingkungan Hidup Kebersihan dan Pertamanan Kabupaten Garut. 2014. Kajian daya dukung dan daya tampung lingkungan kawasan penyamakan kulit Sukaregang Kabupaten Garut. DLHKP Kabupaten Garut. Garut.

Dzikron M. 2014. Aplikasi chrome recovery dalam industri penyamakan kulit [Skripsi]. Fakultas Teknik, Universitas Islam Bandung. Bandung.

Effendi H. 2003. Telaah kualitas air bagi pengelolaan sumber daya dan lingkungan perairan. Kanisius. Yogyakarta.

El-Hadi RM dan Nasution A. 2012. Prototype simulasi instalasi pengolahan air limbah cair industri penyamakan kulit dengan sistem daur ulang [Prosiding]. Seminar Nasional Penelitian dan PKM: Sains, Teknologi dan Kesehatan.

Gupta VK and Suhas. 2009. Application of low-cost adsorbents for dye removala review. Journal of Environmental Management 90(8):2313-42.

Itodo AU, Khan ME and Feka DP. 2018. Tannery wastewater evaluation and remediation: adsorption of trivalent chromium using commercial and regenerated adsorbents. Journal of Water Technology and Treatment Methods 1(1):1-8.

[Kemenperin] Kementerian Perindustrian. 2015. Rencana induk pembangunan industri nasional 2015-2035. Kemenperin. Jakarta. 
Kurniasari L, Riwayati I dan Suwardiyono. 2012. Pektin sebagai alternatif bahan baku biosorben logam berat. Momentum 8(1):1-5.

Meena A and Rajagopal C. 2002. Comparative studies on adsorptive removal of lead from contaminated water using different adsorbents. Indian Journal of Environmental Protection 22(11):1257-66.

Ningrum D. 2010. Pengaruh industri penyamakan kulit terhadap kualitas lingkungan dan peran pengrajin dalam pengelolaan limbahnya [Prosiding]. Prosiding Seminar Nasional Manajemen Teknologi XI. Program Studi MMTITS.

PerMenLH (Peraturan Menteri Lingkungan Hidup) Nomor 5 Tahun 2014 tentang Baku Mutu Air Limbah.

Pranoto, Masykur A, Fatimah N and Prabawani S. 2018. Fabrication of Sugar palm fiber/andisol soil composites for iron (III) ion, removal from aqueous solution. Oriental Journal of Chemistry 34(1):346-51.

Pratama IMR, Sulhadi dan Aji MA. 2016. Pemanfaatan serabut Cocos nucifera sebagai filter air limbah pewarna tekstil [Prosiding]. Pertemuan Ilmiah XXX HFI Jateng \& DIY. Himpunan Fisika Indonesia Cabang Jateng dan DIY.

Priyadi R, Iskandar R, Nuryatidan R dan Hermawan Y. 2014. Efektivitas teknologi M-Bio pada pengelolaan limbah padat industri penyamakan kulit Sukaregang Garut untuk pertanian ramah lingkungan. Jurnal Bumi Lestari 14(2):180-88.

Priyanto B. 2006. Uji toksisitas air limbah penyamakan kulit menggunakan metode penghambatan pertumbuhan Lemna sp. Jurnal Teknik Lingkungan $7(2): 212-18$.

Putri YD, Holik HA, Musfiroh I dan Aryanti AD. 2014. Pemanfaatan tanaman eceng-ecengan (Ponteridaceae) sebagai agen fitoremediasi dalam pengolahan limbah krom. IJPST 1(1):20-25.

Ringo ES, Kusrijadi A dan Sunarya Y. 2013. Penggunaan metode elektrokoagulasi pada pengolahan limbah industri penyamakan kulit menggunakan aluminium sebagai sacrificial electrode. Jurnal Sains dan Teknologi Kimia 4(2):96-107.

Tatra SJ. 2014. Pemanfaatan karbon aktif dengan aktivator $\mathrm{H}_{3} \mathrm{PO}_{4}$ dari limbah padat agar sebagai penjerap pada limbah cair industri penyamakan kulit [Tesis]. Departemen Teknologi Hasil Perairan, Fakultas Perikanan dan Ilmu Kelautan, Institut Pertanian Bogor. Bogor.

Wardhani E, Dirgawati M dan Alvina IF. 2011. Kombinasi proses presipitasi dan adsorpsi karbon aktif dalam pengolahan air limbah industri penyamakan kulit. Itenas Library 1-16.

Weiner RF and Matthews RA. 2003. Environmental engineering 4th edition. Butterworth-Heinemann. Massachusetts. 